\title{
REPORT
}

\section{A Report on the 14th Annual Meeting of the Environment for Development (EfD) Initiative}

\author{
Tanay Raj Bhatt, ${ }^{*}$ Vidisha Chowdhury, ${ }^{* *}$ and E. Somanathan ${ }^{* * *}$
}

The 14th Annual Meeting of the Environment for Development (EfD) Initiative (https://efdinitiative.org/) was held virtually during 16-20 November 2020. The EfD Annual Meeting is an integral part of the EfD Initiative's commitment to quality research and active interaction, focusing on the application of environmental economics in the Global South. It brings together researchers from various EfD centres, their collaborators, and other key stakeholders for the exchange of research ideas, discussion of research proposals, and presentation of results from EfD projects.

The five-day event included four keynote addresses by eminent scholars which focused on specific issues within the realms of environmental, agricultural, and gender economics.

The keynote address on the first day was delivered by Urvashi Narain, senior environmental economist of the World Bank. She described the World Bank's research on air pollution, now considered the greatest public health problem at the global level. Environmental economists at the World Bank have developed a methodology for assigning monetary value to the loss of life and risks to health from pollution, which governments can use to evaluate mortality and health damages from air pollution against the costs imposed by regulations to curb air pollution. The cost of air pollution

\footnotetext{
* Centre for Research on the Economics of Climate, Food, Energy, and Environment (CECFEE), Indian Statistical Institute; 7, S. J. S. Sansanwal Marg, New Delhi 110016, India; bhatt97.trb@gmail.com.

** CECFEE; vidishachowdhury2@gmail.com.

${ }^{* * *}$ CECFEE; som@isid.ac.in. $\bowtie$

Copyright (C) Bhatt, Chowdhury and Somanathan 2021. Released under Creative Commons Attribution-NonCommercial 4.0 International licence (CC BY-NC 4.0) by the author.

Published by Indian Society for Ecological Economics (INSEE), c/o Institute of Economic Growth, University Enclave, North Campus, Delhi 110007.
}

ISSN: 2581-6152 (print); 2581-6101 (web).

DOI: https://doi.org/10.37773/ees.v4i1.373 
was estimated at about $10 \%$ of the GDP in China, and about $8 \%$ of the GDP in India, Sri Lanka, and Cambodia, based on data from 2013.

The second keynote address was delivered by Menale Kassie of the International Centre of Insect Physiology and Ecology on adoption of new technologies for sustainable development. In particular, Kassie focused on how research on insects holds the key to green development. He discussed state-of-the-art research in this area that provides evidence on how substituting fishmeal or soy-based animal feed with insects would be a Pareto improvement. Not only is the insect-based feed more cost-efficient, but evidence also indicates that farm animals that are provided with insectbased feed yield much more output (eggs, pig meat, etc.). This has important implications since, as Kassie argued, animal feed accounts for up to $60-70 \%$ of production costs in the industry. Moreover, compared to traditional feed, the emissions intensity of insect-based feed is far lower. In addition to animal feed, insects can also be used to manufacture fertilizers, which have been shown to be at least as effective as traditional fertilizers. In fact, the high protein content of insects and the minimal resource requirement of insect farming make it ideal for sustainably tackling the problem of global malnutrition. In conclusion, Kassie mentioned that the socio-economic impacts of investing in insects are likely to be massive, contributing to poverty alleviation, lowering emissions, improving waste management, boosting employment generation, and increasing savings.

On the third day, Jan Steckel from the Mercator Research Institute on Global Commons and Climate Change (MCC) highlighted the growing need for research on emissions pricing in low-income countries and factors that shape its feasibility. From a climate perspective, rising energy demands in poor countries and their growing contribution to global emissions call for such climate policies. From an economic point of view, carbon taxes have the potential to generate significant revenues that could be used to lower other distortionary taxes, increase public investment, and support disproportionately affected communities. However, a major challenge facing emissions pricing, as Jan pointed out, is the lack of public acceptance. He emphasized that the political acceptability of such policies is governed by people's perceptions about their distributional effects, impacts on individual freedom, and effectiveness. Social norms and political background may also play a major role in shaping public opinion.

The keynote speech on the fourth day approached climate change through a gender lens. In her keynote address, Farzana Afridi from the Indian Statistical Institute, Delhi, discussed the gender-differentiated impacts of technological shocks and extreme weather conditions on labour usage. She emphasized that the effect of technological change or shocks on women 
can vary between the home and market; indeed, there exists a gender-based division of labour such that women bear a disproportionate burden of the domestic work. Using empirical findings from her recent work, she showed that while productivity-enhancing cooking technologies, such as liquefied petroleum gas (LPG), can improve women's welfare, farm mechanization that reduces the need for manual weeding may adversely affect women, rendering their labour redundant. In the case of negative production shocks such as droughts, women's farm labour and earnings reduce significantly relative to those of men, and the former are less likely to migrate. Consequently, such shocks can exacerbate earnings and labour market inequalities between men and women. Formulating policies to respond to such gender-differentiated impacts requires reskilling the female workforce, ensuring safe mobility, and improving women's access to work.

Each day of the meeting had five parallel presentation sessions in which participants discussed around 80 research papers and 15 research proposals. These covered EfD thematic areas such as agriculture, air quality, biodiversity, carbon pricing, climate change, conservation, energy, experiments, fisheries, forestry, gender, health, land, policy design, urban spaces, waste, and water. Amongst these, some papers investigated the impacts of climate change on crop yields and labour productivity; others looked at the effects of clean cooking fuels such as electricity and LPG on air quality and health; a few analysed factors driving sustainability in fisheries; and some explored how climatic, institutional, and economic factors influence COVID-19 morbidity.

The general assembly on the final day began with an address by Pam Fredman, President of the International Association of Universities and Chair of the EfD Board, in which she pointed out the practices that need to be undertaken to achieve the objectives that EfD has set for itself. In this context, she discussed the challenges that we face and that the network has already achieved positive results. She focused, particularly, on the role that higher education has to play, and how the EfD network, academics, and international organizations must engage with each other and universities to address those objectives. This was followed by EfD Director Gunnar Köhlin discussing the scope of the EfD against the background of the ongoing pandemic and what lies ahead in terms of the EfD's objectives.

This year, Zhaoyang Liu was adjudged the winner of Peter Berck's Best Discussion Paper Award for his paper on valuing a water purification scheme of forests. Gunnar Köhlin's Best MSc Dissertation Award was conferred upon Camilo De Los Rios Rueda for his work on overlapping institutions and deforestation in the Columbian Amazon. 
For the first time at an EfD conference, Rebecca Klege discussed the status of gender equity within the network. She pointed out that despite significant improvements, the progress of gender equity within economics departments has somewhat stalled since 2009. Studies have shown that relative to STEM (science, technology, engineering, and medicine) subjects, female participation is quite low in economics. Moreover, since most EfD member institutions are housed within economics departments, the status of gender equity in the network is far from ideal. Except for centres in Kenya and India, there are huge gender disparities in EfD member institutions. Given this background, Klege discussed the short- and longterm goals of the EfD to address this issue and announced the upcoming gender equity report.

This year's annual meeting brought together a large number of researchers from various countries to discuss a host of issues within the ambit of sustainable development. Despite the virtual nature of the conference, there was a high level of academic and social interaction and effective building of networks. In conclusion, the annual meeting facilitated wide-ranging academic discussion and collaboration within the EfD community and provided a much-needed platform for the discussion of pressing environmental concerns. 